\title{
Data flow between RFID devices in a modern restricted access administrative office
}

\author{
Waszkowski Robert ${ }^{1, a}$, Chodowska Agata ${ }^{2}$, Kiedrowicz Maciej ${ }^{1}$, Nowicki Tadeusz ${ }^{1}$, Wesołowski Zbigniew ${ }^{1}$, Worwa \\ Kazimierz ${ }^{1}$ \\ ${ }^{1}$ Military Academy of Technology, Faculty of Cybernetics, Kaliskiego 2, 00-908 Warsaw, Poland \\ ${ }^{2}$ Tecna Sp. z o.o., Kasprowicza 103a/9, 01-823 Warsaw, Poland
}

\begin{abstract}
The paper presents models of data flow between RFID devices in a modern restricted access administrative office. The presented diagrams are the result of the analytical work performed by the multidisciplinary team of experts. The team was composed of IT specialist, security systems specialists and employees of the secret office. The presented models include the fact that the facilities in the secret office (cabinet, sluice, photocopier, desks) are equipped with the RFID reader, which allows to immediately read the documents that are within their reach.
\end{abstract}

\section{Introduction}

This paper presents models of data flow between RFID devices in a modern restricted access administrative office.

The research results are part of an $R \& D$ project, partially supported by the National Centre for Research and Development under grant No. DOBRBIO4/006/13143/2013.

The science project - entitled "Electronic system for lifecycle management of documents of various level of confidentiality" - focuses on the use of the latest information and communication technologies related to Radio-Frequency Identification (RFID) and biometrics. The aim of completing this research project is to build and implement a prototype of a modern secret office designed to manage documents of various levels of confidentiality. The project covers all processes that take place in a secret office and the use of devices equipped with the RFID transmitter / receiver modules. The focus of the research is not only on documents and data carriers, but also on all secret office equipment (cabinets, desk, copying machines and entry/exit control devices) and appropriate software (the RFIDoc system).

The integration of all software and hardware components in a single system using the dedicated software involves the need to establish strict rules for data exchange between them. In the following chapters, the data flow between these components is described for different cases of application in the office.

\section{Types of interfaces between RFIDoc systems and office devices}

\subsection{Monitoring}

The monitoring interface receives every event sent by special devices in the secret office. The device sends signals thanks to CrossTalk system agents. The information on events is received from the following devices:

- Cabinet

- Switching on the cabinet

- Opening the door

- Closing the door

- Sluice (entry/exit zones)

- Closing the entrance door

- Closing the exit door

- Trays

- Switching on the device

- Placing the document on tray

- Taking the document from the tray

- Tunnel

- Switching on the device

- Placing the document in tunnel

- Taking the document from the tunnel

- Photocopier

- Which documents are copied and by whom

The monitoring interface communicates through http protocol. If any event occurs, the device sends an XML message to the rfiDoc system.

\subsection{Authentication}

The authentication interface authenticates access to various devices in the secret office, in particular to :

1. Passage through sluices:

When a person enters a sluice, the system sends the following types of signals:

\footnotetext{
a Corresponding author: robert.waszkowski@wat.edu.pl
} 
- The OK signal means consent for passage and opens the exit door, and then allows a person to enter the next zone. - The NOK signal means lack of consent and re-opens the entrance door and allows the person to leave the sluice.

\section{Opening cabinets}

When placing an ID card on a special spot in the cabinet, the cabinet sends a request for authentication. The cabinet opens the door once it receives permission from the rfiDoc system.

\section{Copying documents}

The interface communicates with the device and informs which materials may be copied, in which number and by whom.

Once the copy button is pressed, the photocopier saves in a special output folder (Archive-OUT) the documents that are to be copied as pdf files, with the following formal name:

[sequential_number(pages)]_[JobId]_[user's_identificatio n_number]_[id_tagu_rfid].pdf

Where:

- sequential_number(pages) - paper sheet number

- JobId - internal identification number of the task

- user's_identification_number - ID number of the ID card
- id_tagu_rfid - ID of the RFID tag of the document The verification process may commence once the following file appears: [jobId].ok

After the rfiDoc system recognizes the file [jobId].ok, it starts the verification process and checks which documents may be copied. After verification, the system copies the verified files from the output folder (keeping the file names) into the input folder (Archive-IN). The rfiDoc system signalizes the end of the verification process by placing the [jobId].ok file in the input folder $\mathrm{w}$ (Archive-IN). Once the photocopier recognizes the file, it starts copying

\section{Data flows between the system and RFID devices}

The rfiDoc system communicates with the devices via CrossTalk AppCenter and Cosmos. The Cosmos system ensures communication between the photocopier and rfiDoc, whereas CrossTalk AppCenter supports communication between rfiDoc and such devices as sluice, cabinet, tray and tunnel.

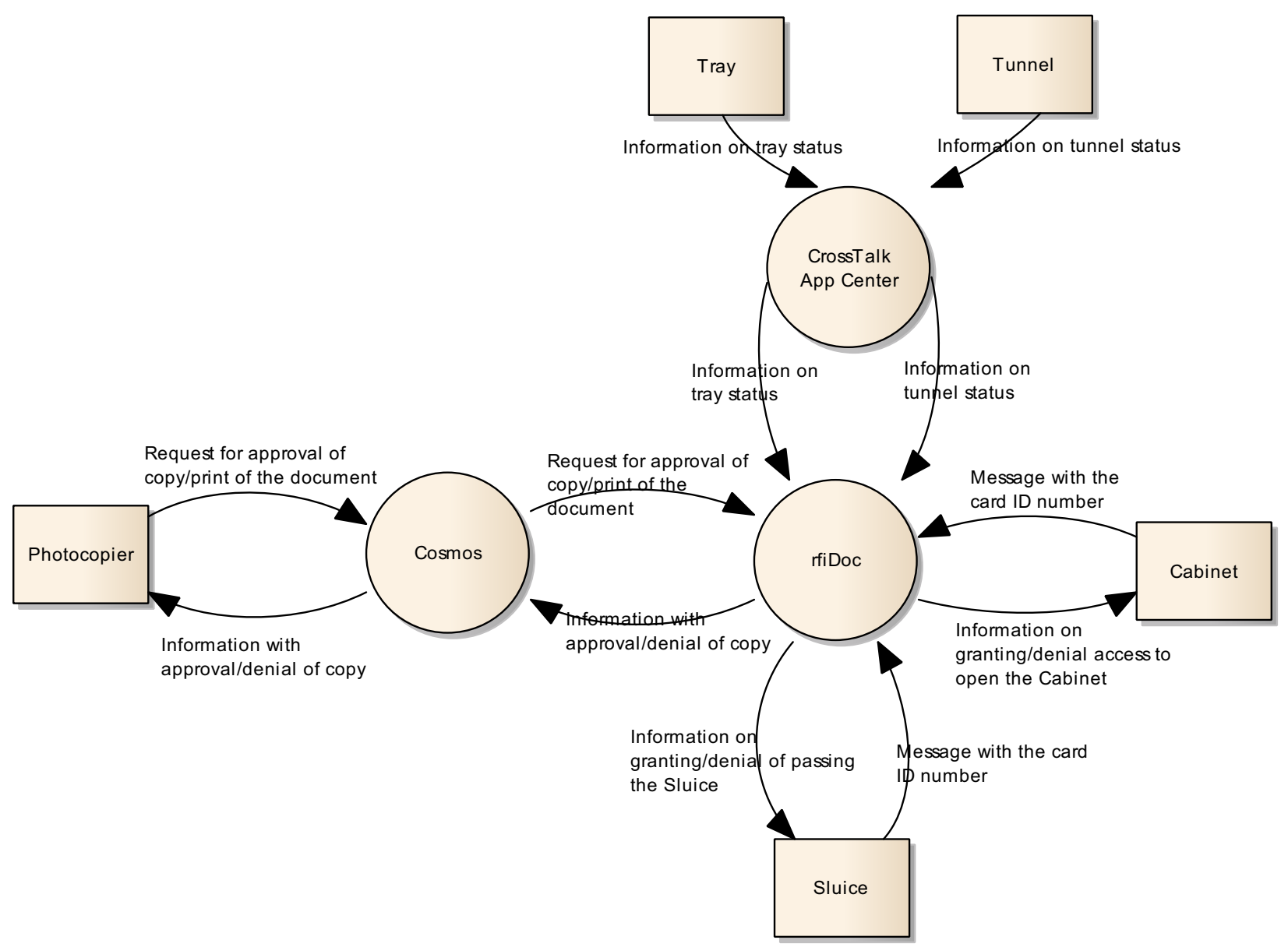

Figure 1. Diagram of flows between the rfiDoc system and Cosmos and CrossTalk systems as well as devices used in the secret office. Source: own elaboration. 
The following subchapters describe communication and data flow between the rfiDoc system and other devices in the secret office.

\subsection{Switching on the sluice}

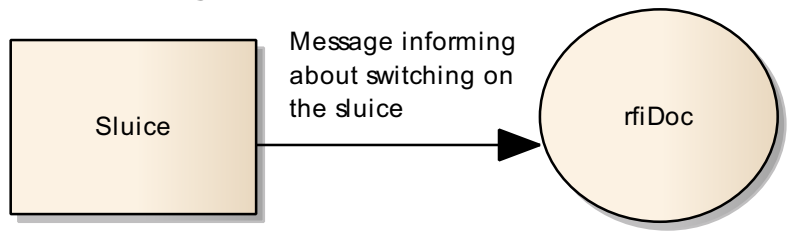

Figure 2 Diagram of data flow between the sluice and rfiDoc system - switching on the sluice

The following table presents the types and informational scope of the messages used when switching on the sluice.

\begin{tabular}{|c|c|c|}
\hline $\begin{array}{c}\text { Type of } \\
\text { event }\end{array}$ & $\begin{array}{c}\text { Type of } \\
\text { message }\end{array}$ & \multicolumn{1}{c|}{ Description } \\
\hline $\begin{array}{c}\text { Switching } \\
\text { on the sluice }\end{array}$ & Event & $\begin{array}{l}\text { When switching on the sluice, the signal } \\
\text { informing about the event, together with } \\
\text { the list of all RFID tags currently on the } \\
\text { device, is sent. }\end{array}$ \\
\hline
\end{tabular}

Example of the text of the HTTP POST request in the form of XML:

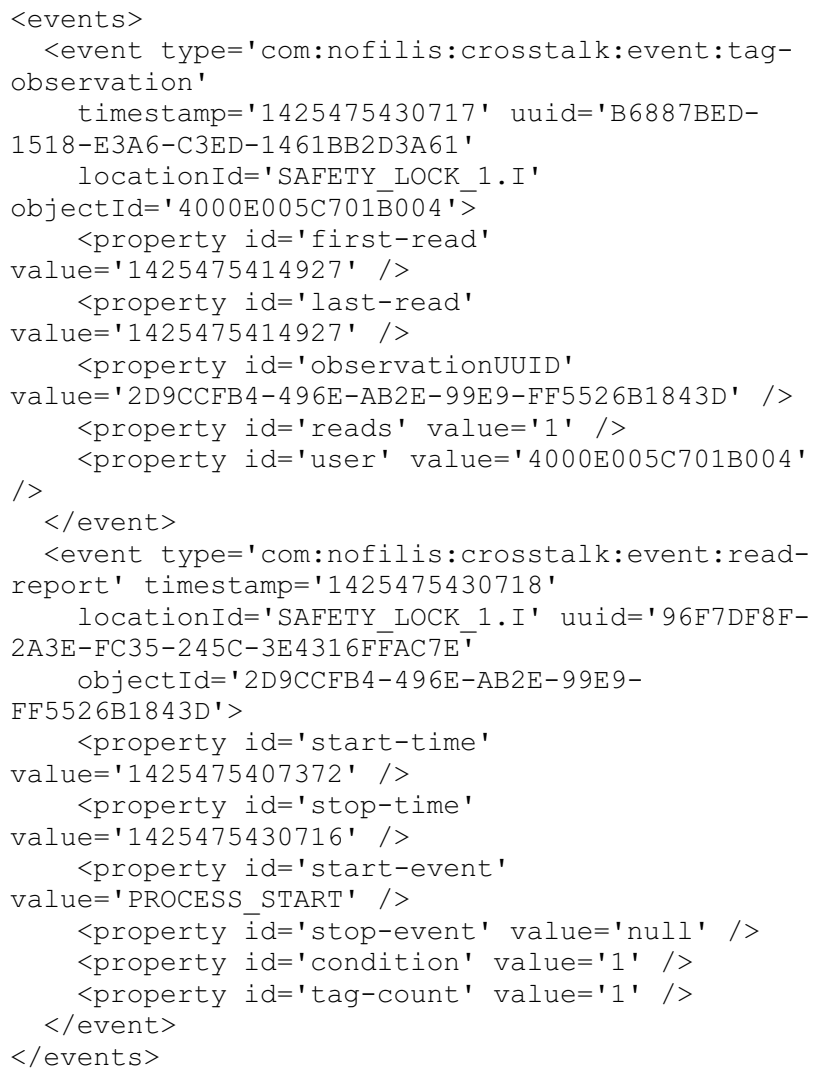

\subsection{Access to the secret office}

Only duly authorized persons will have access to the secret office. Every person visiting the secret office must produce an ID card with the RFID chip. To enter the secret office, it is necessary to go through a sluice. The sluice is composed of the entrance door (outside), which allow to enter the secret office from its environment, and exit door (inside), which allow to exit the secret office to its environment.

When entering the secret office through the sluice, a given person is verified by the rfiDoc system in terms of his/her authorization. At this time, the sluice sends a message about closing the entrance door. The system verifies the authorization of the person entering the secret office and then sends a message about consent or lack of consent to enter the secret office. If the person is authorized to enter the secret office, the exit door opens. Otherwise, when the person may not enter the secret office - the entrance door allowing to leave the sluice opens.

The following diagrams show data flows between the sluice and the rfiDoc system. The first diagram shows the data flow in the event when the person entering the secret office is not duly authorized.

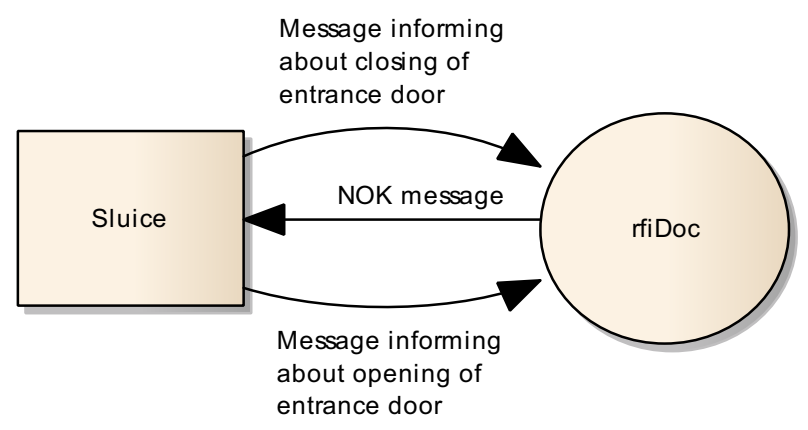

Figure 3 Diagram of data flow between the sluice and the rfiDoc system - no authorization to enter the secret office

In case of no authorization to enter the secret office, the sluice sends messages in the following form:

\begin{tabular}{|l|l|l|}
\hline $\begin{array}{l}\text { Type of } \\
\text { event }\end{array}$ & $\begin{array}{l}\text { Type of } \\
\text { message }\end{array}$ & Description \\
\hline $\begin{array}{l}\text { Opening } \\
\text { of the } \\
\text { entrance } \\
\text { door }\end{array}$ & Event & $\begin{array}{l}\text { When opening the entrance } \\
\text { door of the sluice, the device } \\
\text { sends the information about } \\
\text { this event, together with the } \\
\text { information that did it and the } \\
\text { list of all RFID tags currently } \\
\text { on the device. }\end{array}$ \\
\hline
\end{tabular}

Example of the text of the HTTP POST request in the form of XML:

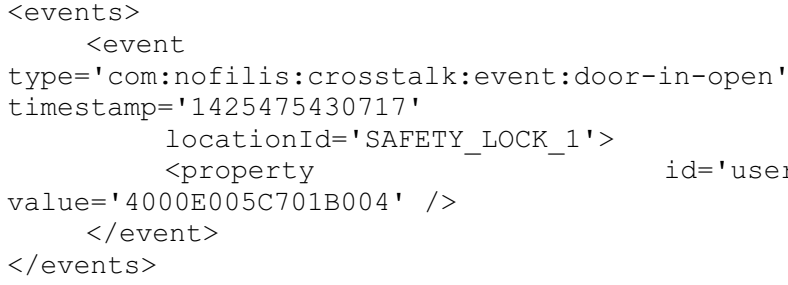

\begin{tabular}{|c|l|l|}
\hline $\begin{array}{c}\text { Closing of } \\
\text { the } \\
\text { entrance } \\
\text { door }\end{array}$ & Event & $\begin{array}{l}\text { When closing the entrance door of } \\
\text { the sluice, the device sends the } \\
\text { information about this event, } \\
\text { together with the information that }\end{array}$ \\
\hline
\end{tabular}




\begin{tabular}{|l|l|l|}
\hline & $\begin{array}{l}\text { did it and the list of 1 RFID tags } \\
\text { currently on the device. }\end{array}$ \\
\hline
\end{tabular}

Example of the text of the HTTP POST request in the form of XML:

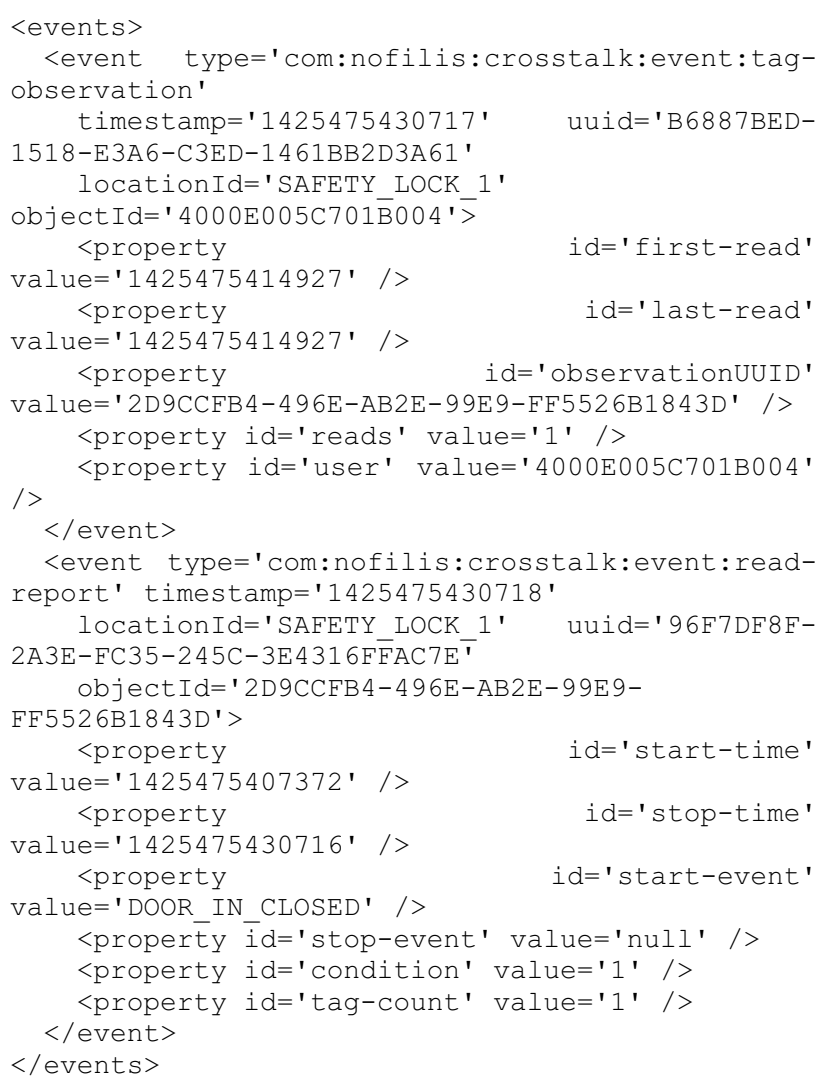

The second diagram presents the data flow in the event when the person entering the secret office is duly authorized.

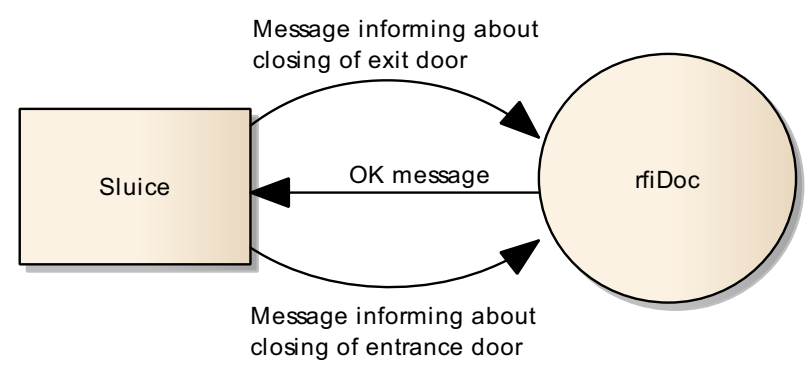

Figure 4 Diagram of data flow between the sluice and the rfiDoc system - positive authorization to enter the secret office

In case of positive authorization to enter the secret office, the sluice sends messages in the following form:

\begin{tabular}{|c|c|l|}
\hline $\begin{array}{c}\text { Type of } \\
\text { event }\end{array}$ & $\begin{array}{c}\text { Type of } \\
\text { message }\end{array}$ & \multicolumn{1}{c|}{ Description } \\
\hline $\begin{array}{c}\text { Closing of } \\
\text { the } \\
\text { entrance } \\
\text { door }\end{array}$ & Event & $\begin{array}{l}\text { When closing the entrance door } \\
\text { of the sluice, the device sends } \\
\text { the information about this } \\
\text { event, together with the } \\
\text { information who did it and the } \\
\text { list of all RFID tags currently }\end{array}$ \\
\hline
\end{tabular}

\begin{tabular}{|l|l|}
\hline & on the device \\
\hline Example of the text of the HTTP POST request in the
\end{tabular} form of XML:

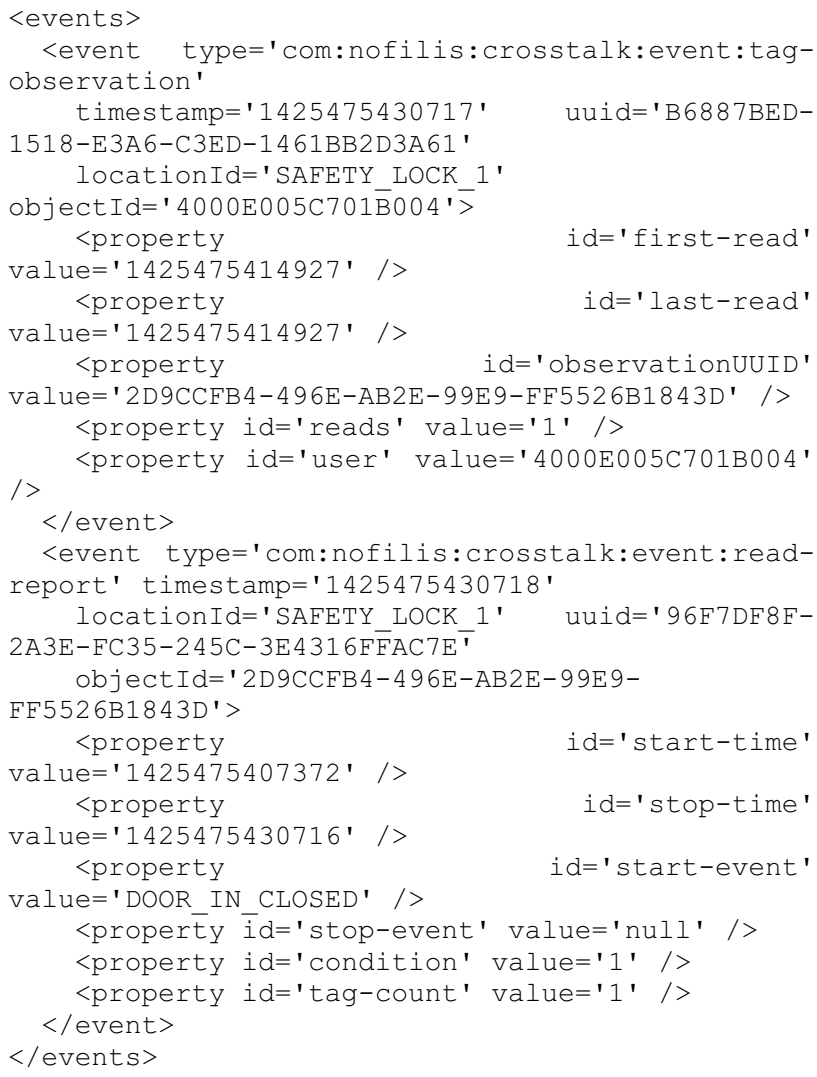

\begin{tabular}{|c|l|l|}
\hline $\begin{array}{c}\text { Opening } \\
\text { of the } \\
\text { entrance } \\
\text { door }\end{array}$ & Event & $\begin{array}{l}\text { When opening the exit } \\
\text { door of the sluice, the } \\
\text { device sends the } \\
\text { information about this } \\
\text { event, together with the } \\
\text { information who did it and } \\
\text { the list of all RFID tags } \\
\text { currently on the device }\end{array}$ \\
\hline
\end{tabular}

Example of the text of the HTTP POST request in the form of XML:

<events>

<event

type= ' com: nofilis: crosstalk: event: door-out-open ' timestamp $=$ ' 1425475430717 '

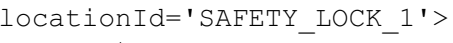

\subsection{Exit from the secret office}

The person leaves the secret office through the sluice. The inside door of the sluice opens each time, whereas the outside door opens depending on whether the person leaving the secret office takes with him/her any documents or not, to do which such person is authorized. Any attempt to take the documents without proper 
authorization is signalized by the rfiDoc system, and, additionally affects the decision to open the outside door of the sluice.

The person leaving the secret office with or without documents, with respect to which (s)he is authorized, may freely go through the sluice and leave the area of the secret office. The system verifies the authorization of such person and then ,allows" the sluice to open the outside door. After closing the entrance door of the sluice, a message informing about the rfiDoc system about this event is sent. The rfiDoc system sends the information about allowing or forbidding to exit the secret office. The information is passed in the form of the NOK and OK messages.

The following diagrams present the data flow between the sluice and the rfiDoc system. The first diagram shows the data flow when the person leaving the secret office does not take any documents.

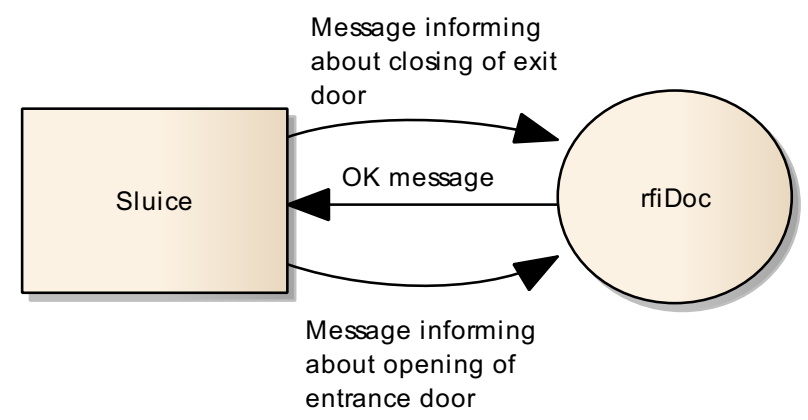

Figure 5 Diagram of data flow between the sluice and the rfiDoc system - leaving the secret office without any documents

In the event when the person leaving the secret office does not take any documents, the sluice sends messages with the following content:

\begin{tabular}{|c|c|l|}
\hline $\begin{array}{c}\text { Type of } \\
\text { event }\end{array}$ & $\begin{array}{c}\text { Type of } \\
\text { message }\end{array}$ & \multicolumn{1}{c|}{ Description } \\
\hline $\begin{array}{c}\text { Closing of } \\
\text { the } \\
\text { entrance } \\
\text { door }\end{array}$ & Event & $\begin{array}{l}\text { When closing the entrance door } \\
\text { of the sluice, the device sends } \\
\text { the information about the event, } \\
\text { together with the information } \\
\text { who did it and the list of all } \\
\text { RFID tags currently on the } \\
\text { device }\end{array}$ \\
\hline
\end{tabular}

Example of the text of the HTTP POST request in the form of XML:

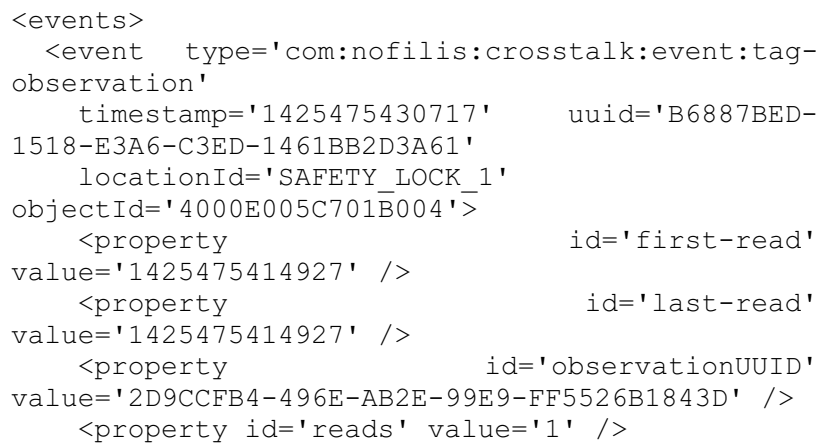

<property id='user' value='4000E005C701B004'

$</$ event $>$

<event type='com:nofilis:crosstalk:event:readreport' timestamp='1425475430718'

locationId='SAFETY LOCK 1' uuid='96F7DF8F2A3E-FC35-245C-3E4316FFAC7 ${ }^{\top}$

object Id= ' 2D DCCFB4-496E-AB2E-99E9-

FF5526B1843D'>

<property

value='1425475407372' />

<property

value='1425475430716' />

$<$ property

value='DOOR IN CLOSED' /

<property id='stop-event' value='null' />

<property id='condition' value='1'/>

<property id='tag-count' value='1' />

$</$ event $>$

$</$ events $>$

\begin{tabular}{|l|l|l|}
\hline $\begin{array}{c}\text { Closing the exit } \\
\text { door }\end{array}$ & Event & $\begin{array}{l}\text { When closing } \\
\text { the exit door of } \\
\text { the sluice, the } \\
\text { device sends } \\
\text { the information } \\
\text { about this } \\
\text { event, together } \\
\text { with the } \\
\text { information } \\
\text { who did it and } \\
\text { the list of all } \\
\text { RFID tags } \\
\text { currently on the } \\
\text { device }\end{array}$ \\
\hline
\end{tabular}

Example of the text of the HTTP POST request in the form of XML:

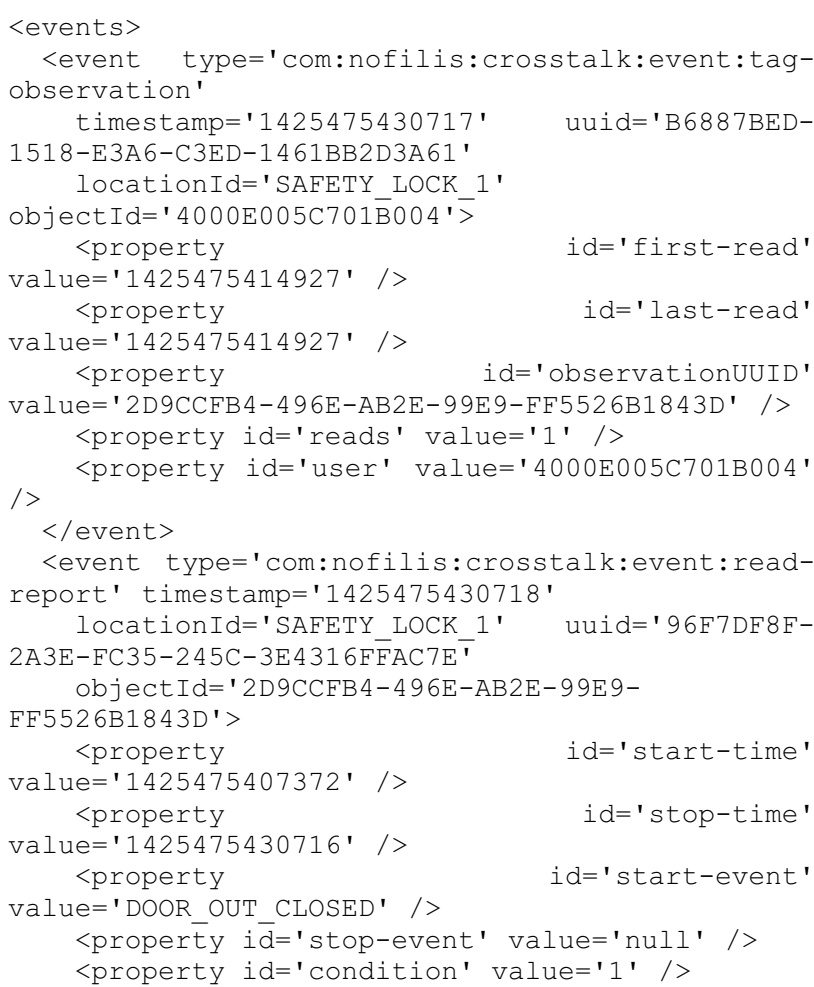




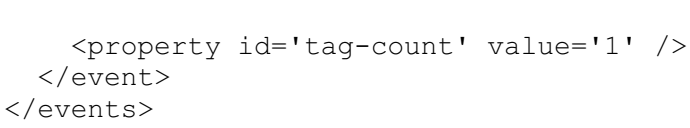

The second diagram presents the data flow in the event when the person leaving the secret office is authorized to take documents outside the area of the secret office.

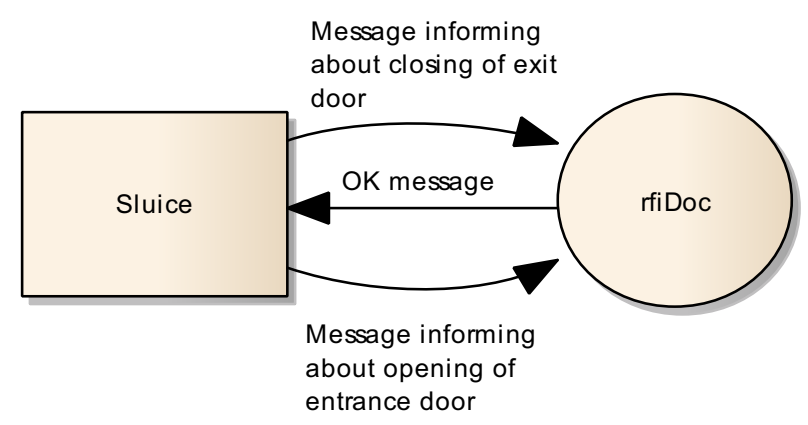

Figure 6 Diagram of the data flow between the sluice and the rfiDoc system - authorized exit from the secret office with the documents

In the event when the person leaving the secret office takes the documents, to do which (s)he is authorized, the sluice sends messages with the following content:

\begin{tabular}{|c|c|l|}
\hline $\begin{array}{c}\text { Type of } \\
\text { event }\end{array}$ & $\begin{array}{c}\text { Type of } \\
\text { message }\end{array}$ & \multicolumn{1}{c|}{ Description } \\
\hline $\begin{array}{c}\text { Closing of } \\
\text { the } \\
\text { entrance } \\
\text { door }\end{array}$ & Event & $\begin{array}{l}\text { When closing the entrance door } \\
\text { of the sluice, the device sends } \\
\text { the information about this } \\
\text { event, together with the } \\
\text { information who did it and the } \\
\text { list of all RFID tags currently in } \\
\text { the }\end{array}$ \\
\hline
\end{tabular}

Example of the text of the HTTP POST request in the form of XML:

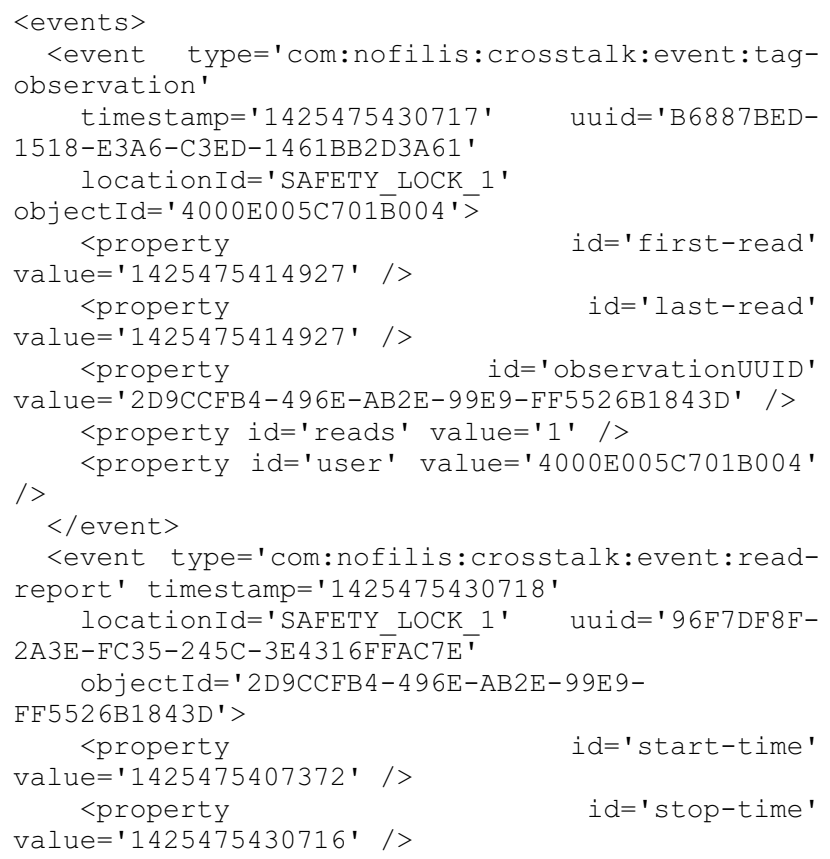

$<$ property

value='DOOR_IN_CLOSED' />

<property $\bar{i} d='$ stop-event' value='null' />

<property id='condition' value='1' />

<property id='tag-count' value='1' />

$</$ event $>$

$</$ events $>$

\begin{tabular}{|l|l|l|}
\hline $\begin{array}{c}\text { Closing of the } \\
\text { exit door }\end{array}$ & Event & $\begin{array}{l}\text { When closing the } \\
\text { exit door of the } \\
\text { sluice, the device } \\
\text { sends the } \\
\text { information } \\
\text { about this event, } \\
\text { together with the } \\
\text { information who } \\
\text { did it and the list } \\
\text { of all RFID tags } \\
\text { currently on the } \\
\text { device }\end{array}$ \\
\hline
\end{tabular}

Example of the text of the HTTP POST request in the form of XML:

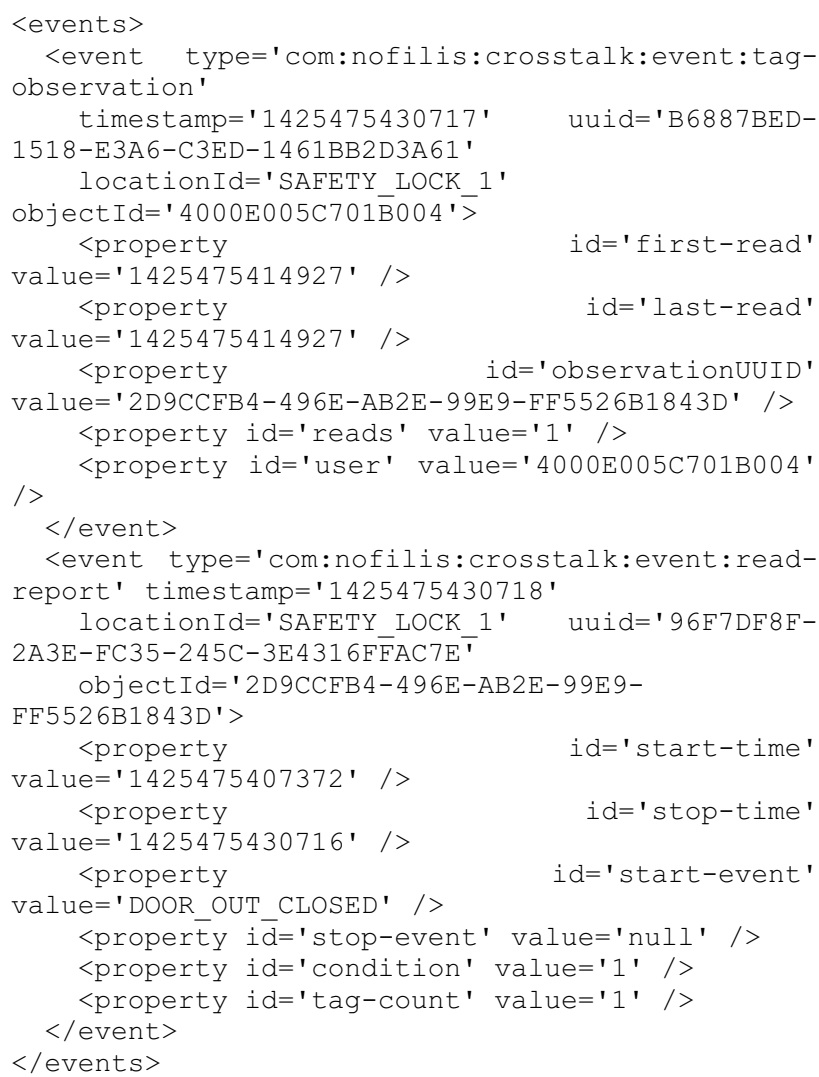

The third diagram presents the data flow in the event when the person leaving the secret office is not authorized to take the documents outside the area of the secret office. 


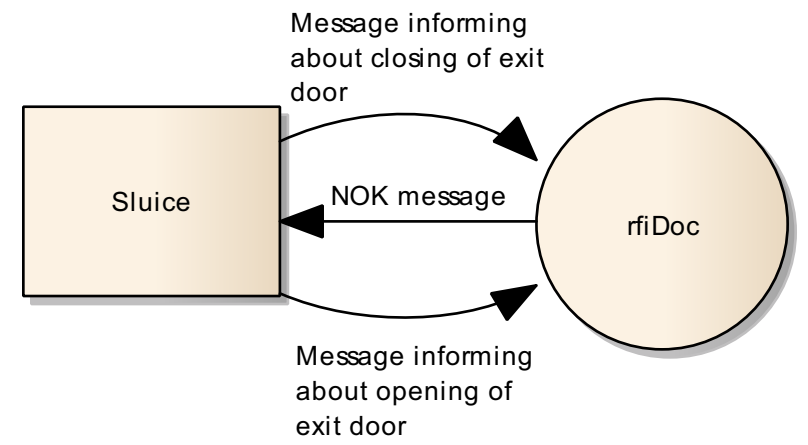

Figure 7 Diagram of the data flow between the sluice and the rfiDoc system - unauthorized exit from the secret office with the documents

\begin{tabular}{|c|c|l|}
\hline $\begin{array}{c}\text { Type of } \\
\text { event }\end{array}$ & $\begin{array}{c}\text { Type of } \\
\text { message }\end{array}$ & \multicolumn{1}{c|}{ Description } \\
\hline $\begin{array}{c}\text { Opening } \\
\text { of the exit } \\
\text { door }\end{array}$ & Event & $\begin{array}{l}\text { When opening the exit door of } \\
\text { the sluice, the device sends the } \\
\text { information about this event, } \\
\text { together with the information } \\
\text { who did it and the list of all } \\
\text { RFID tags currently on the } \\
\text { device }\end{array}$ \\
\hline
\end{tabular}

Example of the text of the HTTP POST request in the form of XML:

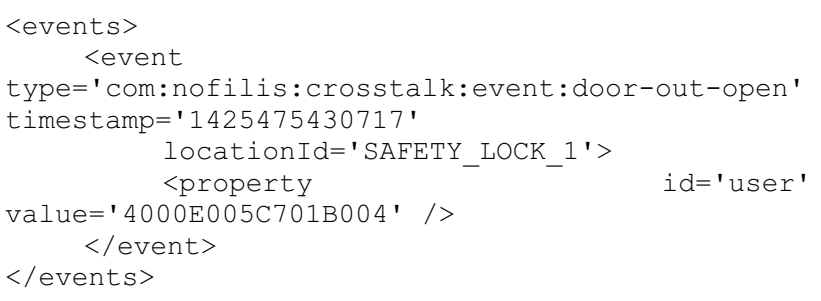

\begin{tabular}{c|c|l|}
$\begin{array}{c}\text { Closing of the } \\
\text { exit doors }\end{array}$ & Event & $\begin{array}{l}\text { When closing the exit door } \\
\text { of the sluice, }\end{array}$
\end{tabular}

Example of the text of the HTTP POST request in the form of XML:

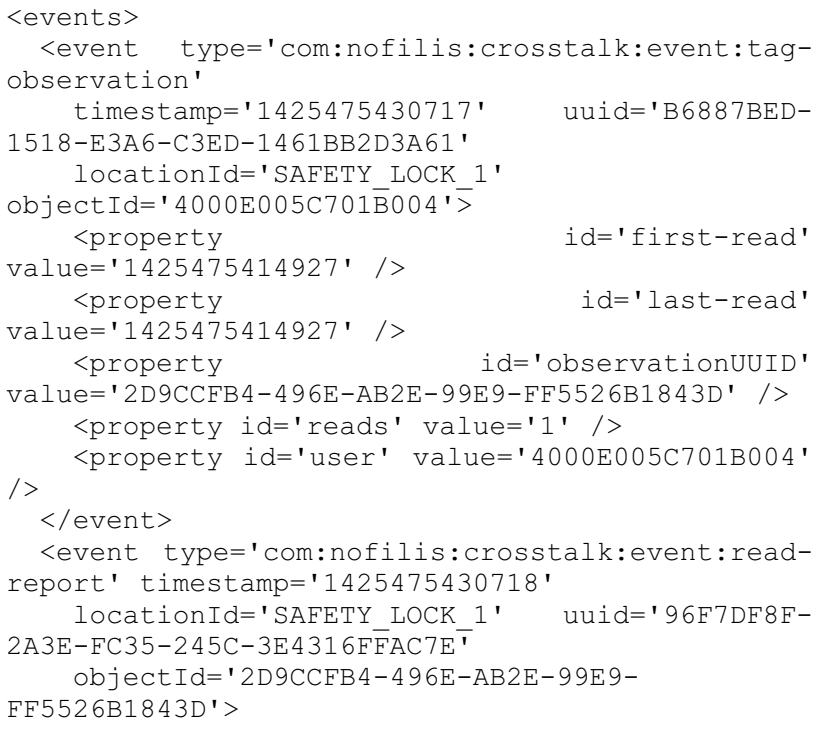

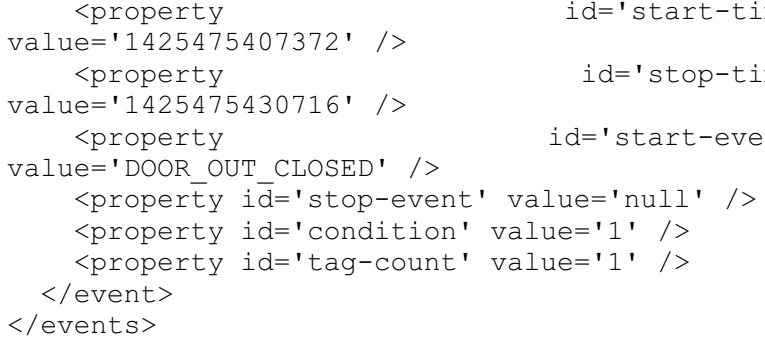

\subsection{Handling the cabinet}

The rfiDoc system provides control over authorization of the persons working with documents stored in the cabinets in the secret office. Every person staying within the area of the secret office must produce the ID card with the RFID chip. The devices in the secret office are equipped with the RFID reader, which allows full control of the operations performed in the secret office.

Only authorized persons may take the document out of the cabinet or put it back. Both operations are preceded by identification by the ID card with the RFID chip. Depending on the rights vested with the person working The cabinet sends to the rfiDoc system a message about an identifier of the card of the person trying to get access to the documents and information about closing and opening of the cabinet. The system sends the following messages to the cabinet:

- OK- if the person is authorized to open the cabinet,

- NOK- if the person is not authorized to open the cabinet,

- The message about the exceeded time for opening the cabinet.

Each of the above-mentioned cases was presented on the following diagrams. The first diagram shows the data transfer between the cabinet and the rfiDoc system in the event when the access to the cabinet is authorized.

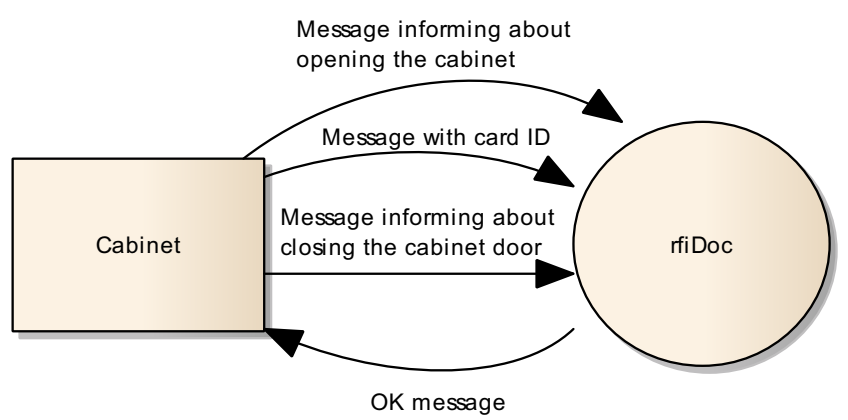

Figure 8 Diagram of the data flow between the cabinet and the rfiDoc system - authorized opening of the cabinet

\begin{tabular}{|c|c|l|}
\hline $\begin{array}{c}\text { Type of } \\
\text { event }\end{array}$ & $\begin{array}{c}\text { Type of } \\
\text { message }\end{array}$ & \multicolumn{1}{c|}{ Description } \\
\hline $\begin{array}{c}\text { Opening } \\
\text { of the } \\
\text { door }\end{array}$ & Event & $\begin{array}{l}\text { When opening the door of the } \\
\text { cabinet, the device sends the } \\
\text { information about this event, } \\
\text { together with the information } \\
\text { who did it and the list of the } \\
\text { RFID tags currently in the } \\
\text { cabinet }\end{array}$ \\
\hline
\end{tabular}


Example of the text of the HTTP POST request in the form of XML:

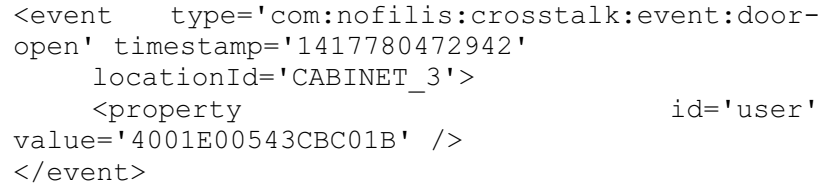

\begin{tabular}{|l|l|l|}
\hline $\begin{array}{c}\text { Closing } \\
\text { the door }\end{array}$ & Event & $\begin{array}{l}\text { When closing the door, the device } \\
\text { sends the information about this } \\
\text { event, together with the information } \\
\text { who did it and the list of the RFID } \\
\text { tags currently in the cabinet }\end{array}$ \\
\hline
\end{tabular}

Example of the text of the HTTP POST request in the form of XML(addition of RFID tag):

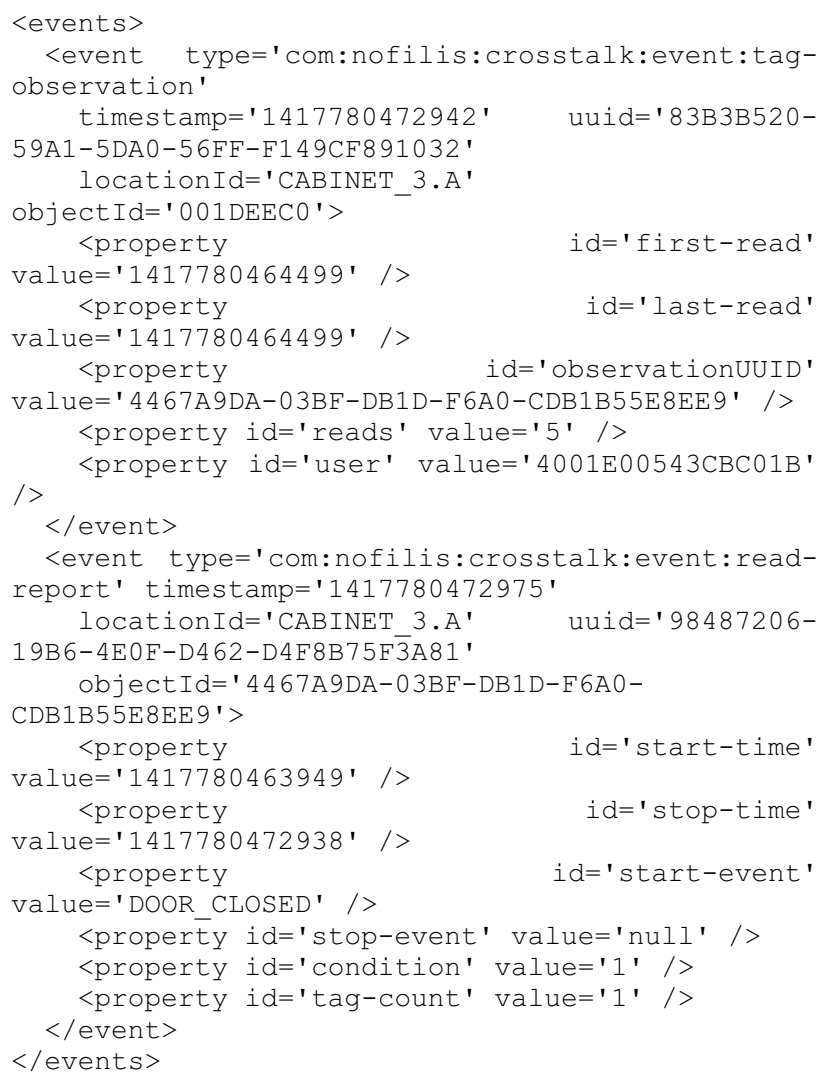

Example of the text of the HTTP POST request in the form of XML(removal of RFID tag):

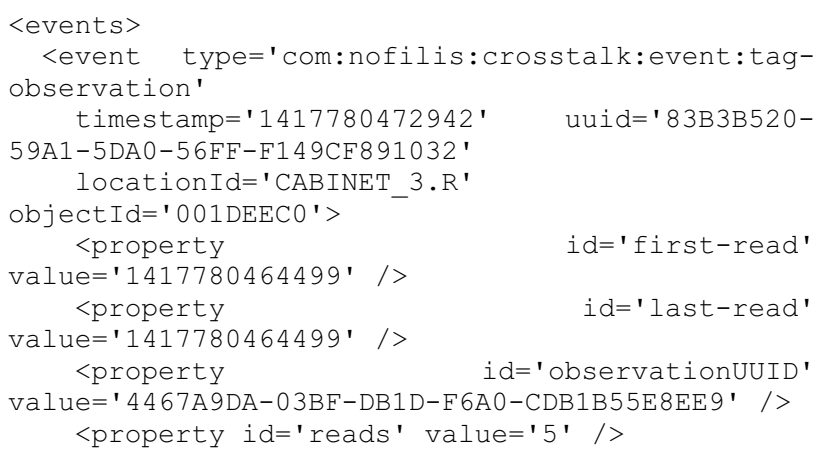

<property id='user' value='4001E00543CBC01B'

$</$ event $>$

<event type='com:nofilis:crosstalk: event:readreport' timestamp='1417780472975'

locationId='CABINET 3.R' uuid='98487206-

19B6-4E0F-D462-D4F8B75F 3 A 81

object Id = ' $4467 \mathrm{~A} 9 \mathrm{DA}-03 \mathrm{BF}-\mathrm{DB} 1 \mathrm{D}-\mathrm{F} 6 \mathrm{AO}-$

CDB1B55E8EE9'>

$<$ property

value='1417780463949' />

$<$ property

value='1417780472938' />

$<$ property

value='DOOR CLOSED' $/>$

$$
\begin{gathered}
\text { id='start-time' } \\
i d=\text { 'stop-time' } \\
i d=\text { 'start-event' }
\end{gathered}
$$

<property id='stop-event' value='null' />

<property id='condition' value='1' />

<property id='tag-count' value='1'/>

\begin{tabular}{|c|c|c|}
\hline Pressing ID card & $\begin{array}{l}\text { Question - } \\
\text { answer }\end{array}$ & $\begin{array}{l}\text { When pressing the ID } \\
\text { card, the device sends } \\
\text { the information about } \\
\text { this event together } \\
\text { with the card } \\
\text { identifier, which } \\
\text { cause the event. The } \\
\text { device waits for } \\
\text { approval to open the } \\
\text { door of the cabinet. }\end{array}$ \\
\hline
\end{tabular}

$</$ event $>$

$</$ events $>$

Example of the text of the HTTP POST request in the form of XML:

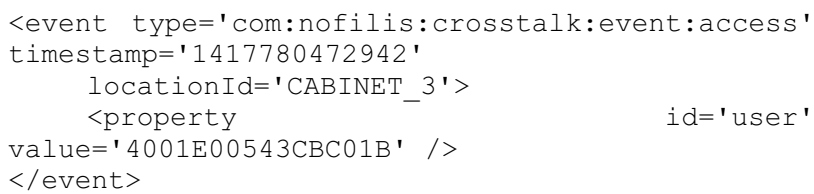

The second diagram refers to the case when the ID card holder is not authorized to open the cabinet.

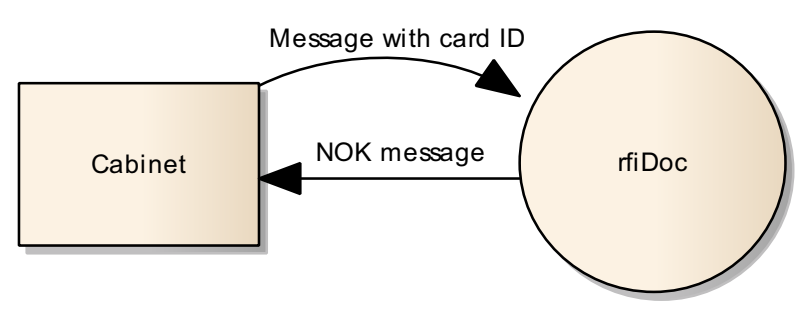

Figure 9 Diagram of data flow between Cabinet and rfiDoc system - not authorized access to the cabinet

\begin{tabular}{|c|l|l|}
\hline Type of event & $\begin{array}{c}\text { Type of } \\
\text { message }\end{array}$ & \multicolumn{1}{|c|}{ Description } \\
\hline Pressing ID card & $\begin{array}{c}\text { Answer - } \\
\text { question }\end{array}$ & $\begin{array}{l}\text { When pressing the } \\
\text { ID card, the device } \\
\text { sends the } \\
\text { information about } \\
\text { this event, together } \\
\text { with the card } \\
\text { identifier, which } \\
\text { caused the event. } \\
\text { The device waits for }\end{array}$ \\
\hline
\end{tabular}




\begin{tabular}{|l|l|l|}
\hline & $\begin{array}{l}\text { approval to open the } \\
\text { door of the cabinet }\end{array}$ \\
\hline
\end{tabular}

Example of the text of the HTTP POST request in the form of XML:

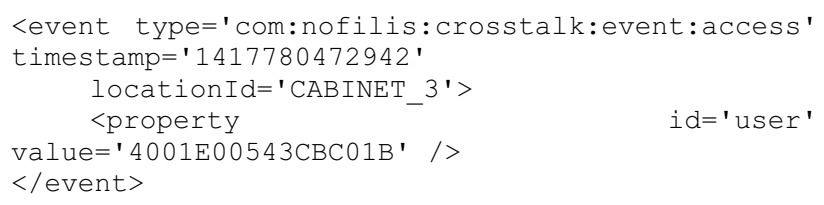

\subsection{Copying of documents}

The rfiDoc system stores authorization to the documents that are in the secret office. The following operations may be performer on the document: copying, printing or scanning. The copying and scanning is performed with the use of a special photocopier including the RFID reader.

To copy the document, authentication by means of the RFID chip card is essential. The photocopier sends to the rfiDoc system the information containing the data identifying the person who wants to copy the document. The copying process commences, during which the rfiDoc system verifies rights to certain documents. The documents, to which the copying party is authorized, are transferred to the Archive-IN folder and only such documents will be copied. Other documents are not copied.

The following diagrams show the data flow between the photocopier and the rfiDoc system. The first diagram shows the data flow for the event when the copying party is authorized to copy the document.

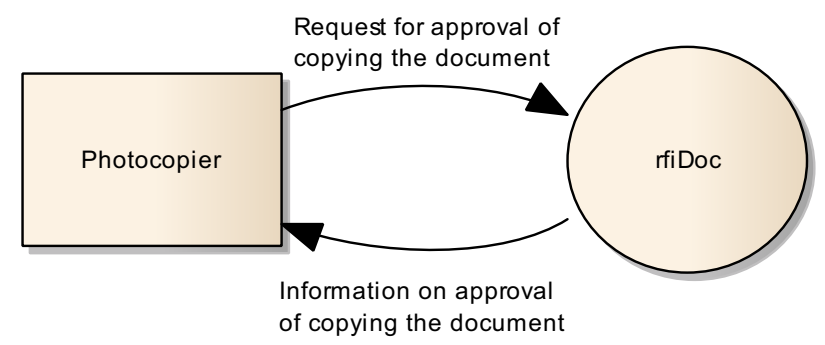

Figure 10 Diagram of the data flow between the photocopier and the rfiDoc system - authorized copying

The second diagram shows the data flow for the event when the copying party is not authorized to copy the document.

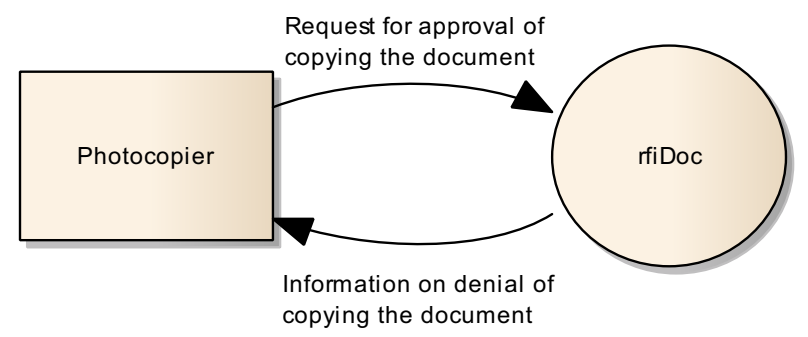

Figure 11 Diagram of the data flow between the photocopier and the rfiDoc system - unauthorized copying

\subsection{Switching on the tray}

After switching on the tray, the device sends the signal informing about this event. The message contains a list of the RFID tags on the device.

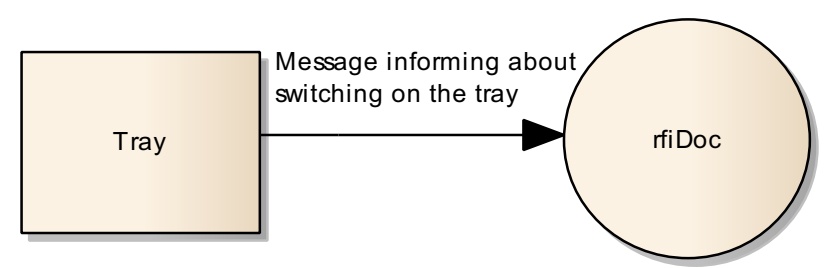

Figure 12 Diagram of the data flow between the tray and the rfiDoc- switching on the tray

\begin{tabular}{|c|c|c|}
\hline $\begin{array}{c}\text { Type of } \\
\text { event }\end{array}$ & $\begin{array}{c}\text { Type of } \\
\text { message }\end{array}$ & \multicolumn{1}{c|}{ Description } \\
\hline $\begin{array}{c}\text { Switching } \\
\text { on the } \\
\text { device }\end{array}$ & Event & $\begin{array}{l}\text { When switching on the } \\
\text { device, the signal informing } \\
\text { about this event, together with } \\
\text { the list of all RFID tags } \\
\text { currently on the device }\end{array}$ \\
\hline
\end{tabular}

Example of the text of the HTTP POST request in the form of XML:

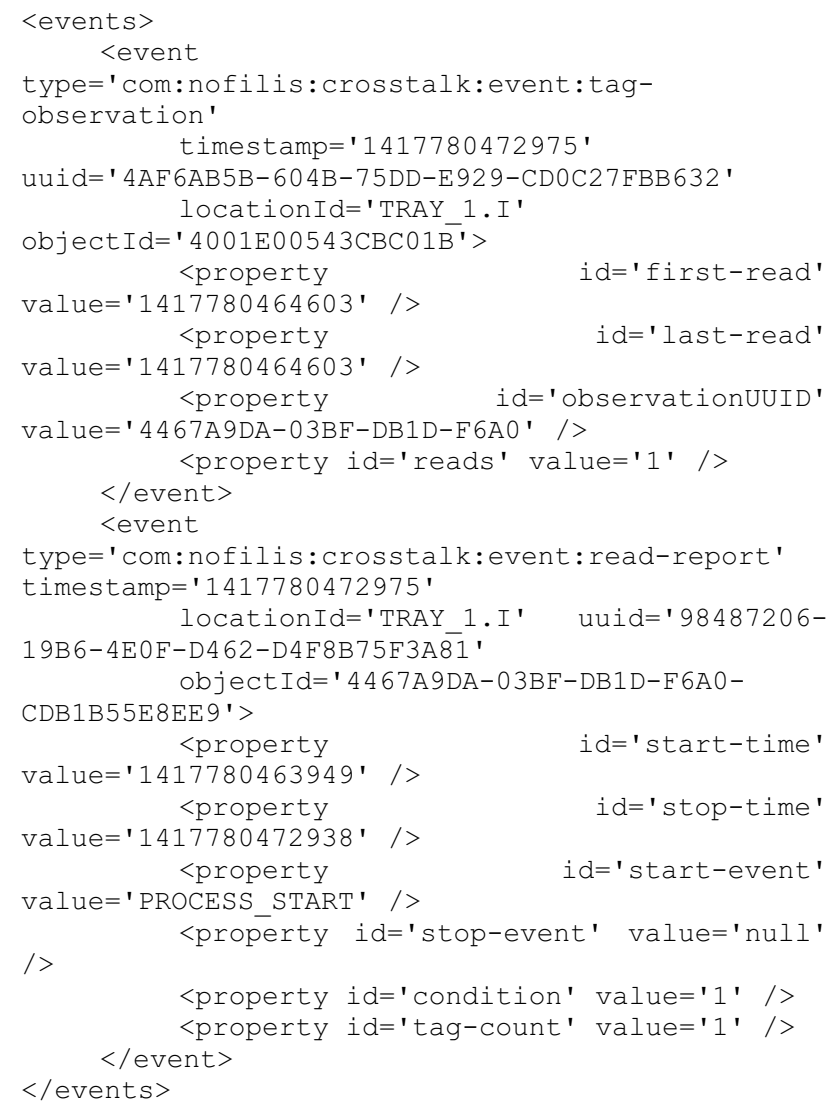

\subsection{Placement of the document on tray}

Each document stored in the secret office has an appropriate RFID tag. All metadata of the documents are stored in the rfiDoc system. The rfiDoc system has data 
Example of the text of the HTTP POST request in the form of XML:

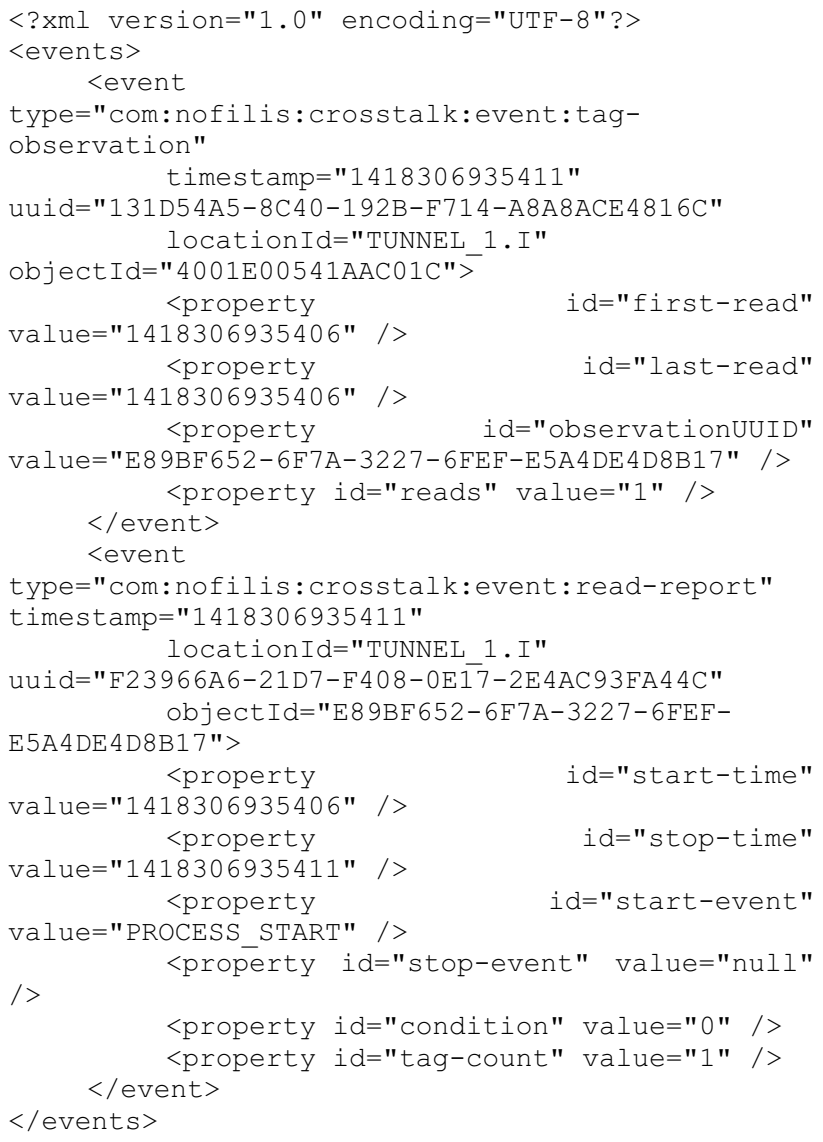

\subsection{Moving the document through the tunnel}

All documents stored in the secret office have appropriate tunnelRFID tags allowing their identification and placement. Taking the document out of the secret office is possible only upon prior grant of authorization. The document may be taken out of the secret office if the person carries it through the sluice or tunnel. The tunnel identifies the documents, which are stored therein. When the documents are moved through the tunnel, it affects the transfer of data with the RFID tags on the documents through the tunnel. Therefore, the control of the movement of the documents inside different zones of the secret office or outside the office is maintained.

The following diagram present the data flow between the tunnel and the CrossTalk and rfiDoc systems.

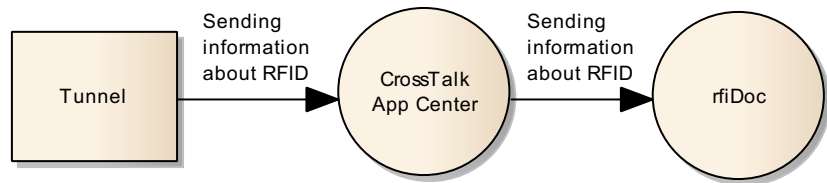

Figure15 Diagram of the data flow between the tunnel and the CrossTalk and rfiDoc systems

\begin{tabular}{|c|c|c|}
\hline Type of event & $\begin{array}{c}\text { Type of } \\
\text { message }\end{array}$ & Description \\
\hline $\begin{array}{c}\text { Detection of the } \\
\text { document }\end{array}$ & Event & $\begin{array}{l}\text { After detecting the } \\
\text { document, the device } \\
\text { sends the information }\end{array}$ \\
\hline
\end{tabular}

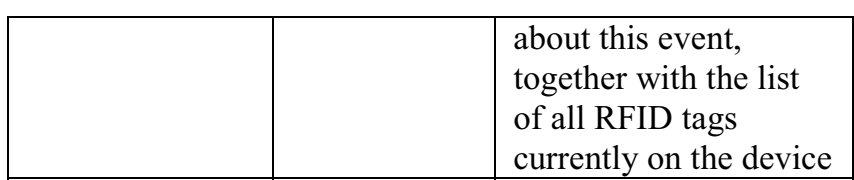

Example of the text of the HTTP POST request in the form of XML:

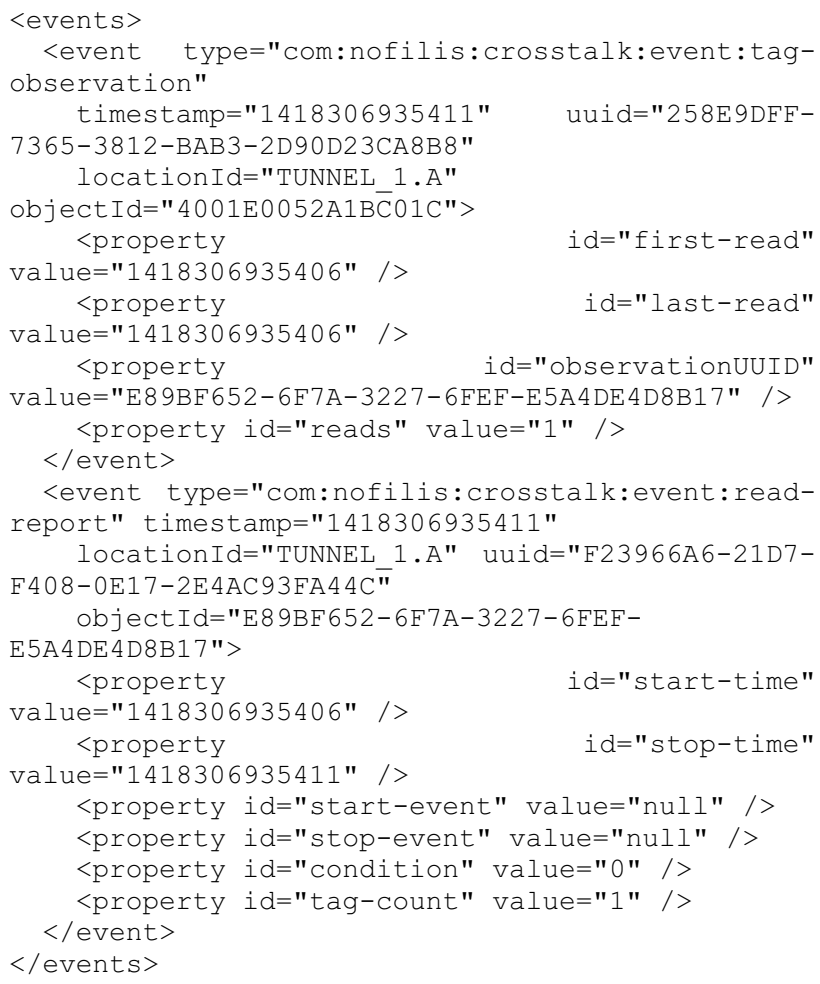

\begin{tabular}{|l|l|l|}
$\begin{array}{c}\text { Deletion of the } \\
\text { document }\end{array}$ & $\begin{array}{l}\text { After deleting the } \\
\text { document, the device } \\
\text { sends the information } \\
\text { about this event, } \\
\text { together with the list } \\
\text { of all RFID tags } \\
\text { currently on the device }\end{array}$ \\
\hline
\end{tabular}

Example of the text of the HTTP POST request in the form of XML:

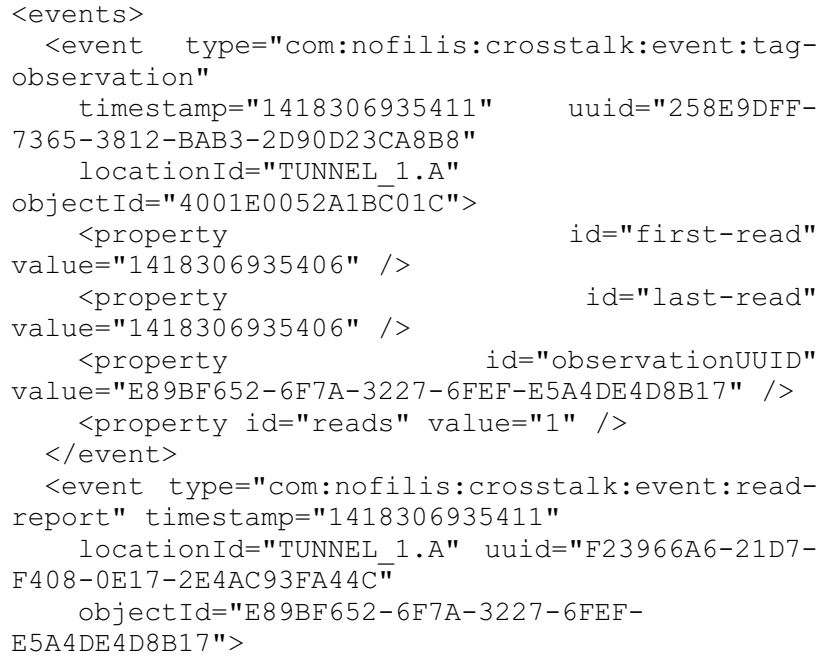

<event type="com:nofilis:crosstalk:event:readreport" timestamp="1418306935411" locationId="TUNNEL_1.A" uuid="F23966A6-21D7F408-0E17-2E4AC93FA44C" 


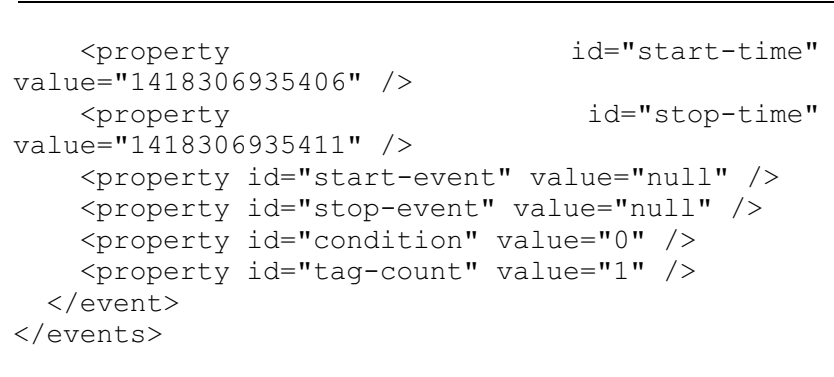

\section{Conclusions}

The dedicated monitoring and authenticating interfaces ensure complete data flow between the devices, which support the work of the secret office and the rfiDoc system. The operations of the secret office are supported by the rfiDoc system and the following equipment: sluice, cabinet, tray, tunnel and photocopier.

The rfiDoc system exchanges with the devices the information on the authorization rights and messages concerning their operation in the secret office. The lack of authorization to operate the device or handle the document stored in the secret office is signalized by way of certain messages sent by the system, which affect the behavior of the equipment. Unauthorized actions are blocked by the rfiDoc system.

\section{References}

1. Orłowski A. Analiza tendencji rozwoju technik RFID oraz laboratorium badawcze technik RFID, Warszawa 2008

2. Patrick J. Sweeney II „RFID for Dummies” Wiley Publishing 2005

3. Szczurkowski M. Roz. Zdalna identyfikacja radiowa obiektów w oparciu o RFID. W: Wytwarzanie i sterowanie polami magnetycznymi dla radiowej identyfikacji obiektów RFID. Rozprawa doktorska, Kraków 2010

4. Techniki inwigilacji, Paweł Kałużny, ISBN/ISSN: 978-83-01-15317-5 , Wydawnictwo Naukowe PWN, Rok wydania 2008

5. Wolf-Ruediger Hansen, Frank Gillert, „RFID for the Optimization of Business Processes,„, str. 95 - 120 (roz. V), Wiley

6. noFilis "CrossTalk AppCenter 3.0 Installation and Administration Guide"

7. Canon UniFLOW documentation - www.canon.com

8. Aurea BPM system documentation - aurea-bpm.com

9. Finkenzeller K., RFID Handbook: Fundamentals and Applications in Contactless Smart Cards and Identification, Second Edition, John Wiley \& Sons (2003)

10. Cole P.H., Ranasinghe D.C., Networked RFID Systems and Lightweight Cryptography, Springer (2008)

11. Zhang Y., Yang L.T., Chen J., RFID and Sensor Networks Architectures, Protocols, Security and Integrations, CRC Press (2009)

12. Paret D., RFID at Ultra and Super High Frequencies. Theory and application, John Wiley \& Sons (2009)
13. Bolic M., Simplot-Ryl D., Stojmenovic I., RFID Systems Research Trends And Challenges, John Wiley \& Sons (2010)

14. Miles S.B., Sarma S.E., Williams J.R., RFID Technology and Applications, Cambridge University Press (2008) 